\title{
Intensitas Serangan Hama Tikus Belukar (Rattus sp) Pada Tanaman Kelapa Sawit (Elaeis guineensis Jacq.) Menghasilkan di Kebun Rakyat Desa Suko Awin Jaya Kabupaten Muaro Jambi
}

\author{
${ }^{1}$ Hayata, ${ }^{* 1}$ Nasamsir dan ${ }^{2}$ Robi Aldinardo \\ ${ }^{1}$ Prodi Agroteknologi, Fakultas Pertanian Universitas Batanghari \\ ${ }^{2}$ Alumni Prodi Agroteknologi, Fakultas Pertanian Universitas Batanghari \\ Jl. Slamet Riyadi, Broni Jambi, 36122. Telp. +62741 60103 \\ ${ }^{*} 1$ email korespondensi : nasamsirsamsir@yahoo.co.id
}

\begin{abstract}
Cultivation of oil palm is inseparable from pests. One of the main pests that attack oil palm plants is the rat class which can cause oil palm plantations get a high losses. The aim of this study was to determine the attacktion intensity of the bush rat (Rattus sp) in Oil Palm smallholder at Suko Awin Jaya Village, Muaro Jambi Regency. The research was carried out from February to April 2021 at the oil palm smallholder specifically farmer group "Ridho Ilahi". The experimental design was unformated trials, and the location was purposively chosen. The location determination of the sample was based on to the initial survey that there was found rats attacktion in this place. Sampling was carried out concurrently at the time fresh fruit bunches harvesting, fruit counting in the bunch, counting the number of fruits eaten by rats, counting good fruit (free from rat pest attacks), and weighing the weight of fresh fruit bunches. Parameters observed were the attacktion level in the land, attacktion intensity, production per hectare, environmental sanitation conditions. The rats attacktion rate of 100\%, means that all sample in one stretch of plantation have been attackted by rats, it was indicated by a bite scars on the harvested fresh fruit bunches. The attacktion intensity of the bush rat pest was 23\%. The average production was 21.6 tons/hectare/year. The sanitation conditions on the land was partially overgrown with weeds and there were piles of midrib in the area between the certain two path of oil palm tree.
\end{abstract}

Keywords : attacktion intensity, rat pest, oil palm

\begin{abstract}
Abstrak. Budidaya tanaman sawit tidak terlepas dari hama. Salah satu hama utama yang menyerang pada tanaman kelapa sawit adalah dari golongan tikus yang bisa menyebabkan kerugian yang tidak sedikit pada perkebunan kelapa sawit. Penelitian ini bertujuan untuk mengetahui intensitas serangan hama tikus belukar (Rattus sp) di kebun Kelapa Sawit Rakyat Desa Suko Awin Jaya Kabupaten Muaro Jambi. Penelitian dilaksanakan pada bulan Februari sampai dengan April 2021 di perkebunan kelapa sawit rakyat kelompok tani Ridho Ilahi. Rancang percobaan dilakukan tidak terformat (Unformated trials), dan lokasi sengaja dipilih. Penentuan lokasi pengambilan sampel berdasarkan survei awal bahwa tempat tersebut di temukan serangan hama tikus. Pegambilan sampel dilakukan seiringan dengan pemanen tandan buah segar, pengamatan menghitung jumlah buah pada tandan, menghitung jumlah buah yang dimakan tikus, menghitung buah yang baik (tidak dimakan tikus), dan menimbang berat tandan buah segar. Parameter yang diamati adalah tingkat serangan di lahan, intensitas serangan, produksi perhektar, kondisi sanitasi lingkungan. Tingkat serangan hama tikus sebesar 100\%, artinya seluruh tanaman sampel dalam satu hamparan pada perkebunan tersebut ditemukan bekas serangan hama tikus berupa bekas gigitan pada tandan buah segar yang telah dipanen. Intensitas serangan hama tikus belukar sebesar 23\%. Rata-rata produksi sebesar 21,6 ton/hektar/tahun. Kondisi sanitasi di lahan sebagian ditumbuhi gulma dan terdapat tumpukan pelepah di gawangan.
\end{abstract}

Kata kunci: Intensitas serangan, hama tikus, kelapa sawit

\section{PENDAHULUAN}

Usaha tani kelapa sawit di desa Suko Awin Jaya Kecamatan Sekernan Kabupaten Muaro Jambi merupakan penghasilan pokok yang dilakukan oleh sebagian masyarakat dengan bekerja sebagai petani kelapa sawit, maka dari itu penduduk di desa Suko Awin Jaya sangat bergantung kepada kebun kelapa sawit untuk memenuhi kebutuhan mereka sehari hari. Di antara banyaknya petani sawit, ada sebagian petani yang memiliki kebun sendiri, namun ada juga yang tidak memiliki kebun sawit sendiri. Mereka yang memiliki kebun mengelola kebun mereka sendiri dengan cara menjadikan pekerjaan mereka sebagai petani sawit ini merupakan pekerjaan pokok. Berbeda dengan petani sawit yang tidak memiliki lahan atau kebun sawit mereka mengelola kebun milik orang lain sebagai mata pencaharian mereka untuk memenuhi kebutuhan keluarga dalam meningkatkan kesejahteraan keluarga mereka (Putra, 2019).

Budidaya tanaman sawit tidak terlepas dari hama. Hama utama yang menyerang pada tanaman kelapa sawit adalah dari golongan tikus yang bisa menyebabkan kerugian yang tidak sedikit pada perkebunan kelapa sawit (Saputra, 2017).

Beberapa jenis tikus yang dapat dijumpai di areal tanaman kelapa sawit adalah tikus belukar (Rattus sp), tikus sawah (Rattus rattus argentiventer), tikus rumah (Rattus rattus diardil). Hama tikus menyerang tanaman semua umur, mulai dari pembibitan hingga tanaman menghasilkan. Pada tanaman menghasilkan (TM) tikus menyerang daging buah (mesocarp) baik buah mentah maupun buah masak. Kondisi tersebut menyebabkan kehilangan produksi 
mencapai 10 -15\% (Fauzi, Paeru, Satyawibawa, dan Widyastuti, 2014). Sedangkan menurut Kalidan (2012), kerusakan pada Tandan Buah Segar akibat serangan hama tikus menyebabkan penurunan hasil produksi sebesar $25 \%$.

Kerusakan buah diperberat dengan masuknya serangga penyerbuk bunga kelapa sawit yaitu kumbang moncong (Elaedobius camerunicus), sehingga kehadirannya meningkatkan serangan tikus, karena kumbang ini merupakan sumber pakan hewani yang juga sangat dibutuhkan oleh tikus (Rulianti, 2010).

Hama tikus menyerang buah mentah dan masak. Serangan hama pada buah mentah menyisahkan bekas keratan (gigitan) yang terlihat seperti bopeng (Saipullah dan Iskarlia, 2018).

Untuk dapat hidup dan berkembang biak, tikus membutuhkan makanan, air, mineral, vitamin, dan lindungan. Makanan yang dibutuhkan oleh tikus terdiri dari golongan besar yaitu karbohidrat lemak, dan protein. Oleh karena itulah hama tikus suka mengerat bunga dan buah tanaman kelapa sawit (Lubis dan Widanarko, 2011).

Berdasarkan hasil analisis terhadap isi lambung tikus diperkebunan kelapa sawit, didapat hasil bahwa $80 \%$ dari pakan yang dikonsumsi oleh tikus adalah buah kelapa sawit, 15\% pakan adalah serangga sedangkan sisanya 5\% adalah pakan yang lain (Kurniawan, 2017).

Pada tanaman kelapa sawit, seekor tikus dapat menghabiskan sekitar 6 sampai 14 gram daging buah per hari dan membawa brondolan (buah lepas matang) ke dalam tumpukan pelepah sebanyak 30 sampai 40 kali lipat dari konsumsinya. Jika populasi tikus dalam 1 hektar berkisar antara 183-522 ekor dan berfluktuasi sangat lambat, maka dapat ditaksir menyebabkan kehilangan minyak sawit mentah atau Crude Palm Oil (CPO) minimal antara 328-962 $\mathrm{kg}$ per hektar per tahun, tidak termasuk brondolan (Direktoral Jenderal Perkebunan, 2012). Menurut penelitian Madusari (2012), hasil sensus serangan hama di perkebunan kelapa sawit menghasilkan, pada tanah mineral adalah sebesar $34,2 \%$

Berdasarkan survey pendahuluan yang dilakukan di perkebunan kelapa sawit kelompok tani Ridho Ilahi KM 64 Desa Suko Awin Jaya didapatkan informasi bahwa sudah ada serangan hama tikus, yang menyebabkan penurunan berat tandan buah segar. Pengamatan langsung dilokasi penelitian, ditemukan tandan buah segar yang sudah dipanen dengan kondisi bagian buah bopeng dan berlubang lebar serta serat buahnya sudah habis.

Penelitian ini bertujuan untuk mengetahui intensitas serangan hama tikus belukar (Rattus sp) pada buah dan produksi tandan buah segar di kebun Kelapa Sawit Kelompok Tani Ridho Ilahi KM 64 Desa Suko Awin Jaya Kabupaten Muaro Jambi.

\section{METODE PENELITIAN}

Penelitian ini telah dilaksanakan di kebun Kelapa Sawit Kelompok Tani Ridho Ilahi km 64 Desa Suko Awin Jaya Kecamatan Sekernan, Kabupaten Muaro Jambi, Provinsi Jambi. Penelitian dilaksanakan pada bulan Februari sampai dengan April 2021.

Bahan yang digunakan dalam penelitian ini antara lain tanaman kelapa sawit varietas yang dikeluarkan oleh Sampurna Agro Sriwijaya yang berumur 15 tahun. Alat yang dipakai adalah lempengan seng (label), cat, timbangan, camera, alat tulis.

Penelitian dilakukan dengan rancangan percobaan tidak terformat (Unformated trials). Lokasi penelitian dipilih secara sengaja (Porpusive) karena pada lokasi tersebut terdapat tanaman yang relatif seragam untuk diteliti.

Penentuan lokasi pengambilan sampel berdasarkan survei awal bahwa tempat tersebut di temukan serangan hama tikus. Ada 5 titik tempat pengambilan sampel masing-masing seluas 1 hektar yang dipilih secara acak dari 20 hektar tanaman yang ada di lahan.

Pengambilan sampel pada penelitian ini menggunakan metode Sistemik Sampling. Populasi tanaman dalam 1 Ha berjumlah 135 batang. Jumlah tanaman yang dijadikan sampel adalah $15 \%$, yaitu 20 batang.

Penentuan nomor urut pohon sampel berdasarkan rumus :

$$
\begin{aligned}
& \qquad \text { Rumus } K=\frac{\mathrm{N}}{\mathrm{n}} \\
& \mathrm{K}=\text { (Nomor urut dan ulangan pemilihan pohon sampel) } \\
& \mathrm{N}=\text { (Jumlah tanaman) } \\
& \mathrm{n}=\text { (Jumlah sampel) }
\end{aligned}
$$

Pegambilan sampel dilakukan seiringan dengan pemanen tandan buah segar. Tandan Buah yang sudah dipanen diletakan disisi masing-masing pohon sampel. Kemudian dilakukan pengamatan mulai dari menghitung jumlah buah pada tandan, menghitung jumlah buah yang dimakan tikus, menghitung buah yang baik (tidak dimakan tikus), dan menimbang berat tandan buah segar tersebut. 
Hayata, Nasamsir dan Robi Aldinardo. Intensitas Serangan Hama Tikus Belukar (Rattus sp) Pada Tanaman Kelapa Sawit (Elaeis guineensis Jacq.) Menghasilkan di Kebun Rakyat Desa Suko Awin Jaya Kabupaten Muaro Jambi

Pameter Yang Diamati dalam penelitian ini meliputi :

Tingkat Serangan Hama Tikus (\%)

Penentuan tingkat serangan hama di lokasi sampel dilakukan menggunakan rumus:

$$
P S=\frac{N h}{N t} \times 100 \%
$$

Keterangan:

PS : Persentase tingkat serangan

$\mathrm{Nh}$ : Jumlah pohon sampel yang tandan buah terserang dalam lokasi pengamatan

$\mathrm{Nt}$ : Jumlah total pohon sampel yang ada di dalam lokasi pengamatan

(Menurut: Supriatna dan Hanedah,2017)

Penentuan Intensitas Serangan Hama Tiap Tanaman (\%),

Tingkat kerusakan akibat serangan hama ditentukan dengan rumus:

$$
\text { IS }=\frac{\sum(n i \times v i)}{Z \times N} \times 100 \%
$$

Keterangan:

IS $\quad$ : Intensitas serangan (\%)

ni : Jumlah tandan dengan nilaiskala ke-i

vi : Nilai skala dari setiap kategori serangan ke-i

$\mathrm{Z} \quad$ : Nilai skala dari kategori serangan yang tertinggi

$\mathrm{N} \quad$ :Jumlah Tandan tanaman yang diamati

(Suhaendah, 2019).

\section{Produksi Buah}

Perhitungan Produksi buah dilakukan dengan cara menimbang tandan buah segar (TBS) yang dipanen dari pohon sampel. Untuk mengetahui produksi buah panen per hektar per tahun menggunakan rumus sebagai berikut :

Di mana,

$$
\text { Produksi }=\mathrm{w} \times \mathrm{x} \times \mathrm{y} \times \mathrm{z}
$$

$\mathrm{w}=$ Rata-rata produksi per pohon sampel

$\mathrm{x}=$ Jumlah panen dalam satu bulan

$\mathrm{y}=12$ bulan dalam setahun

$\mathrm{z}=$ Jumlah tanaman dalam satu hektar

\section{Kondisi Sanitasi Areal Tanaman Sawit}

Pengamatan dilakukan pada tandan buah segar yang di panen, dan kondisi ekologi tanaman yang ada di sekitar tanaman kelapa sawit.

Data hasil pengamatan tingkat serangan, intensitas serangan dan produksi ditabulasi dan dianalisis secara kuantitatif.

\section{HASIL DAN PEMBAHASAN}

\section{Tingkat Serangan Hama Tikus (\%)}

Hasil pengamatan tingkat serangan hama tikus pada tanaman kelapa sawit dalam satu lahan, didapatkan hasilnya seperti pada Tabel 1 berikut.

Tabel 1. Tingkat serangan hama tikus pada tanaman kelapa sawit kelompok tani Rido Ilahi yang diamati bulan Februari Sampai April 2021

\begin{tabular}{cccc}
\hline Lahan Sampel & Total Tanaman Sampel & $\begin{array}{c}\text { Jumlah Tanaman Sampel } \\
\text { Yang Terserang }\end{array}$ & Tingkat Serangan (\%) \\
\hline 1 & 20 & 20 & $100 \%$ \\
2 & 20 & 20 & $100 \%$ \\
3 & 20 & 20 & $100 \%$ \\
4 & 20 & 20 & $100 \%$ \\
5 & 20 & 20 & $100 \%$ \\
\hline Rata-rata Dalam satu hamparan & 20 & 20 & $100 \%$ \\
\hline
\end{tabular}


Pada Tabel 1 dapat dilihat bahwa serangan hama tikus belukar menyerang seluruh tanaman sampel pada perkebunan kelapa sawit kelompok tani Ridho Ilahi di Desa Suko Awin Jaya dengan rata-rata tingkat serangan sebesar $100 \%$, artinya seluruh tanaman sampel dalam satu hamparan pada perkebunan tersebut ditemukan bekas serangan hama tikus berupa bekas gigitan pada tandan buah segar yang telah dipanen.

Tingginya tingkat serangan hama tikus belukar pada lahan dikarenakan tersedianya bahan makanan yang disukai oleh tikus yaitu buah kelapa sawit. Disamping itu kondisi lingkungan yang masih bersemak, terdapat banyak gulma yang tumbuh dilahan dan adanya tumpukan pelepah digawangan (pasar mati) merupakan tempat hidup bagi habitat tikus belukar untuk berlindung, mencari makan, dan bereproduksi. Areal tanaman perkebunan yang besemak memudahkan hama tikus untuk bersarang. Rumput liar dan pelepah yang saling bertumpukan merupakan sarang bagi hama tikus. Tikus pohon termasuk golongan omnivora (pemakan segala), tetapi cenderung untuk memakan bijibijian atau sereal. Tikus pohon memiliki kemampuan fisik yang baik untuk memanjat ini di tunjukkan oleh adanya tonjolan pada telapak kaki yang di sebut dengan footpad yang besar dan permukaan yang kasar. Tikus pohon tidak dapat membuat sarang dengan cara menggali tanah, tetapi membuat sarang diantara pelepa-pelepah daun kelapa sawit atau celah-celah yang ada di pohon (Priyambodo, 2003).

Perkebunan kelapa sawit merupakan habitat yang sesuai dengan Tikus pohon. Selain itu, jenis tikus pohon mempunyai kemampuan dalam memanjat sehinggah banyak di temukan dalam perkebunan kelapa sawit. Sembiring (2011), menyatakan Tikus pohon umumnya di temukan pada tanaman berbagai perkebunan seperti kelapa sawit. Permada (2009), melaporkan bahwa kemampuan $R$. tiomanicus (Tikus pohon) dalam memanjat dan mengerat sangat merugikan pada perkebunan kelapa sawit.

\section{Intensitas Serangan Hama Tikus (\%)}

Hasil pengamatan Intensitas serangan hama tikus pada tanaman kelapa sawit dalam satu lahan, didapatkan hasilnya seperti pada Tabel 2 berikut.

Tabel 2. Intensitas serangan hama tikus pada tanaman kelapa sawit kelompok tani Ridho Ilahi yang diamati pada bulan Februari sampai April 2021.

\begin{tabular}{cc}
\hline Lahan sampel & Intensitas serangan hama tikus (\%) \\
\hline 1 & 22 \\
2 & 24 \\
3 & 23 \\
4 & 25 \\
5 & 21 \\
\hline Rata-rata dalam Satu hamparan & 23 \\
\hline
\end{tabular}

Pada Tabel 2 dapat dilihat bahwa Intensitas serangan hama tikus belukar sebesar 21\% pada lahan 5, dengan rata-rata dalam satu hamparan lahan sebesar 23\%. Nasir (2017) mengatakan, keberadaan tikus pohon juga terkait dengan kemampuan adaptasinya yang tinggi. Jenis tikus pohon merupakan tikus terestrial yang juga banyak ditemukan pada kawasan kebun dan riparian, diduga karena banyak terdapat pohon atau pun belukar yang bisa dijadikan sebagai tempat persembunyian sehingga menjadi tempat yang aman untuk berlindung.

Menurut Rulianti (2010), kehadiran serangga penyerbuk (Eladobeius camerunicus) juga menyebabkan meningkatnya serangan hama tikus karena serangga merupakan sumber pakan hewani yang dibutuhkan oleh tikus.

\section{Produksi Buah}

Hasil perhitungan produksi buah perhektar dalam satu tahun perkebunan kelompok tani Ridho Ilahi di Desa Suko Awin Jaya didapatkan hasilnya seperti pada Tabel 3.

Tabel 3. Rata-rata produksi tandan buah segar pada lahan kelapa sawit kelompok tani Ridho Ilahi Desa Suko Awin Jaya.

\begin{tabular}{cc}
\hline Lahan sampel & Produksi tandan buah segar $\left(\right.$ ton $\left.\mathrm{Ha}^{-1} \mathrm{thn}^{-1}\right)$ \\
\hline 1 & 21,85 \\
2 & 21,70 \\
3 & 21,80 \\
4 & 19,06 \\
5 & 23,61 \\
\hline Rata-rata dalam Satu hamparan & 21,60 \\
\hline
\end{tabular}


Pada Tabel 3 dapat dilihat bahwa produksi tandan buah segar (TBS) yang dihasilkan di lahan perkebunan kelapa sawit kelompok tani Ridho Ilahi Desa Suko Awin Jaya yang tertinggi didapatkan di lahan 1 sebesar 21,85 ton $\mathrm{Ha}^{-1}$ thn $^{-1}$, lahan 2 sebesar 21,7 ton $\mathrm{Ha}^{-1}$ thn $^{-1}$, lahan 5 sebesar 23,61 ton/Ha/tahun, dan terendah didapatkan pada lahan 4 sebesar 19,06 ton $\mathrm{Ha}^{-1} \mathrm{thn}^{-1}$. Rata-rata produksi seluruh lahan sampel dalam satu hamparan sebesar 21,6 ton $\mathrm{Ha}^{-1} \mathrm{thn}^{-1}$.

Serangan hama tikus mengakibat produksi tandan buah segar berkurang, dan pada saat dilakukan penelitian produksi tandan buah segar rata-rata sebesar 21,6 ton/Ha/tahun, hasil ini berkurang bila dibandingkan sebelum adanya serangan hama tikus. Menurut Rajagukguk, (2014) pada tanaman kelapa sawit muda atau TBM, tikus memakan bonggol hingga tanaman mati sedangkan pada tanaman menghasilkan (TM) tikus memakan buah dan bunga sehingga dapat menurunkan produksi. Berdasarkan hasil wawancara dengan petani, bahwa kebun kelompok

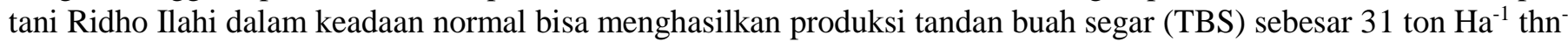
1 .

\section{KESIMPULAN}

Dari hasil penelitian yang telah dilaksanakan dapat dirumuskan :

Intensitas serangan pada lahan kelompok tani Ridho Ilahi tertingi sebesar 25\% dan terendah sebesar $21 \%$ dengan tingkat serangan sebesar 100\%. Dalam keadaan terserang hama tikus (Rattus sp) produksi tandan buah segar (TBS) yang dihasilkan di lahan perkebunan kelapa sawit kelompok tani Ridho Ilahi di Desa Suko Awin Jaya Sebesar 21,6 ton/ha/tahun.

\section{DAFTAR PUSTAKA}

Direktorat Jenderal Perkebunan, (2012). Burung Hantu, Predator Tikus di Areal Tanaman Perkebunan. http://ditjenbun.pertanian.go.id/burung-hantu- predator-tikus-di-areal-tanaman-perkebunan. Di akses pada tanggall 29 desember 2020.

Fauzi, Y., Paeru, H. R., Satyawibawa, I., dan Widyastuti, E.Y. 2014. Buku Kelapa Sawit, Jakarta: Penebar Swadaya (2014). Ekologi kelapa sawit hal; 45, Hama kelapa sawit hal; 147.

Kurniawan, R. M. 2017. Kajian Berbagai Media Umpan Sebagai Campuran Rodentisida Terhadap Hama Tikus. Institut Pertanian Stiper Yogyakarta Jurnal Agromast, Vol.2, No.2, Oktober.

Kalidas, P. 2012. Masalah Hama Kelapa Sawit Dan Strategi Pengelolaannya Untuk Keberlanjutan. Agroteknologi SS11,001

Lubis, E. R. dan Widanarko, A. 2011. Buku Pintar Kelapa Sawit, Jakarta: Agromedia Pustaka. Hal; 200-2002.

Madusari, S. (2012). Pengendalian Hama Tikus Di Perkebunan Kelapa Sawit Dengan Menggunakan Burung Hantu (Tyto alba). Politeknik Kelapa sawit citra Widya Edukasi. Jurnal Citra Widya Edukasi, Vol. 4. No. 1. Hal: $15-16$.

Nasir, M. 2017. Distribusi Mamalia Kecil pada Tiga Lokasi di Sekitar Perkebunan Sawit di Kabupaten Nagan Raya Provinsi Aceh. Prosiding seminar \& rapat tahunan BKS-PTN B MIPA. Medan.

Putra, D. A.(2019). Pengaruh Pendaftaran dan Pengeluaran Petani kelapa sawit Terhadap Keluarga di Desa Suko Awin Jaya Kecamatan Sekernan Kabupaten Muaro Jambi. Skripsi, hal 17-18. Program Study Ekonomi Syariah Fakultas Bisnis dan Ekonomi Islam UIN Sultan Taha Saifuddin Jambi.

Priyambodo, S. 2003. Pengendalian Hama Tikus Terpadu. Penebar Swadaya. Jakarta.

Rulianti, E. 2010. Pedoman Pengamatan dan Pengendalian OPT Penting Kelapa sawit. Ditlinbun, Ditjenbun. http://sinta.ditjenbun.pertanian.go.id/tikus 2/diakses pada tanggal 29 desember.

Rajagukguk, H, B (2014) Pemanfaatan Burung Hantu (Tyto alba) untuk Pengendalian Hama Tikus di Perkebunan Kelapa Sawit. Jurnal Saintech Vol. 06, No.04.

Saipullah dan Iskarlia, R. G., 2018. Pengendalian Hama Tikus PadaTanaman Kelapa Sawit (Elaeis guineensis Jacq.) Fase Tanaman Menghasilkan (TM) di PT Hasnur Citra Terpadu.Prodi Budidaya Tanaman Perkebunan Politeknik Hasnur.Jurnal Sains dan Terapan politeknik Hasnur, Vol.6 No. 1, April 2018, hlm; 7-8.

Saputra, P. 2017. Pemberian Berbagai Jenis Umpan Untuk Mengendalikan Hama Tikus di Perkebunan Kelapa sawit. Institut Pertanian Stiper Yogyakarta Jurnal Agromast, Vol.2. No. 2,

Sembiring, S. 2009. Kajian Biaya Pengendalian Hama Tikus (Rattus sp) Secara Kimiawi dan Pengendalian Secara Hayati Pada Tanaman Kelapa Sawit di Kebun Kerasan Estate PT. Tolan Tiga Indonesia. Skripsi (SIPEF). Medan : STIPAP.

Permada, J. 2009. Tingkat Kejerahan Racun dan Umpan Pada Tikus Sawah, Tikus Rumah, dan Tikus Pohon. Skripsi. Bogor :Institute Pertanian Bogor.

Suhaendah, E. dan Siarudin, M. 2019. Intensitas Serangan Hama Kumbang Moncong Pada Agroforestri Akor (Acacia auriculiformis). Balai Penelitian dan Pengembangan Teknologi Agroforestry. Jurnal Agroforestry Indonesia Vol. 2 No.1, Juli (2019), hlm: 21. 